Popereshnyak 5., Grinenko 5.

\title{
DEVELOPMENT OF AN ONTOLOGICAL MODEL FOR THE DOMAIN OF IT ENTERPRISE SUSTAINABLE DEVELOPMENT
}

Об’єктом дослідження є сталий розвиток IT-підприємства. Одним з найбільш проблемних місць є конкретизація предметної області з урахуванням спещифіки діяльності IT-підприємства. На сьогодні існує певна кількість досліджень в області сталого розвитку, проте, враховуючи специфіку діяльності IT-підприємства, а саме те, що головним його активом є розробка програмного забезпечення, дослідження, пов'язані із аналізом сталого розвитку IT-підприємств, відсутні. Саме тому, перш за все, постає питання у представленні знань про предметну область. В результаті цього, перспективним є розробка моделі, яка б відображала об'єкти домену та зв'язки між ними. Таким засобом є онтології, які є формалізованим представленням знань про домен. У роботі розглядається задача побудови онтологї для предметної області сталого розвитку IT-підприємства, що включає наступні етапи:

- обгрунтування використання онтологій для доменного моделювання;

- коротку характеристику основних кроків побудови онтологї згідно зі стандартом IDEF5.

Наведено збір та аналіз джерел для формування вербальних специфікацій предметної області. Слід зазначити, що розроблена онтологія включає три види представлення: вербальний, графічний та аналітичний. В межах даної роботи наведено тільки два представлення (графічний та аналітичний). Для графічного представлення онтологї була використана схематична мова Schematic Language (SL) cmaндарту IDEF5, що включає в себе кілька видів діаграм для побудови онтологіі. У рамкам проведеного дослідження була використана композиційна схема (Cотроsition Scheтаtics), яка є механізмом графічного представлення складу класів онтології. Для аналітичного представлення було використано числення предикатів, оскільки при збільшенні та уточненні онтології предметної області даний математичний апарат забезпечує надійність результатів. Розроблена онтологія передбачає уточнення та розширення відповідно до вимог проектів, де дана онтологія буде використовуватися, наприклад, для розробки експертної системи для вирішення задач предметної області.

Ключові слова: сталий розвиток, онтологія предметної області, стандарт IDEF5, числення предикатів.

Received date: 13.11 .2018

Accepted date: 28.11 .2018

Published date: 30.06 .2019
Copyright (C) 2019, Popereshnyak S., Grinenko S. This is an open access article under the CC BY license (http://creativecommons.org/licenses/by/4.0)

\section{Introduction}

As a rule, sustainable development is associated only with a part of environmental conservation, but this concept considers the world as an integral system, and therefore each link in this system requires special attention. The area of information technology (IT) is no exception, which should also be considered from the point of view of sustainable development. It should be noted in the study of this issue the work [1], in which attempts were made to formalize this domain through the development of ontology. However, the main attention is paid to assessing sustainable development in terms of only IT enterprise management processes. In the works [2-4], characteristics and features of the sustainable development of enterprises are given, but the specifics of the IT industry are not taken into account. Therefore, the presentation of knowledge about the subject area and the development of a model that reflects domain objects and the relationships between them are relevant. Thus, the object of research is the sustainable development of an IT enterprise. The aim of research is development of an ontological model of the domain of sustainable development of an IT enterprise.

\section{Methods of research}

Ontologies are used in the work according to the IDEF5 standard [5]. «Ontology is a dictionary of domain terms and their formal descriptions (axioms) that limit the content of terms in this dictionary and provide a consistent interpretation of the data used by the dictionary» [5]. Formally, the domain ontology can be defined as a triple: $O=(X, R, F)$, where $X=\left\{x_{i} \mid x_{i}\right.$-notions or terms of domain, $\left.i=\overline{1, n}\right\}, \quad R=$ $=\left\{r_{1}, r_{2}, \ldots, r_{m}\right\}, R: x_{1} \times x_{2} \times \ldots \times x_{n}, F: X \times R-$ finite set of interpretation functions defined on concepts and/or relationships. A special case of the problem of many interpretation functions is a glossary compiled for many concepts.

The advantages of using ontologies are:

- standardization of domain terminology into a single information basis for all project participants; 
- reuse when changing project requirements and development products;

- development management by sharing access to in-

formation to various project participants.

The ontology construction process, according to the IDEF5 methodology, consists of five main actions [6]:

1. The study and systematization of the initial conditions. This action establishes the main goals and contexts of the ontology development project, and also distributes the roles among project members.

2. Collection and accumulation of data. At this stage, the necessary source data are collected and accumulated to build the ontology.

3. Data analysis. This stage is the analysis and grouping of the collected data and is intended to facilitate the construction of terminology.

4. The initial development of ontology. At this stage, a preliminary ontology is formed based on the selected data.

5. Refinement and approval of the ontology. The final stage of the process.

Ontology can be used to solve the following problems:

- coordination of processes, documents, products;

- systems design;

- modeling and reengineering of business processes;

- designing a conceptual scheme.

The following sources were analyzed for domain research:

- The 2030 Agenda for Sustainable Development [7];

- Sustainable Development Strategy of Ukraine until

2030 [8];

- scientific research of scientists in periodicals [9-11];

- monographs [12, 13];

- regulatory framework (standards, laws, etc.) [14-16];

- a survey of domain experts.

\section{Research results and discussion}

A fragment of the developed ontology is given in the work; it contains 31 terms from the subject area of sustainable development of an IT enterprise.

The ontology development process consisted of the following steps:

- definition of domain boundaries, project goals and

domain context;

- data collection and analysis - the study of the sources of terms, the selection of terms for the ontology, the establishment of relations between them, a verbal description of the terms;

- development of ontology - creation of a schematic (graphic) and analytical description of ontology;

- checking the completeness and correctness of the ontology in accordance with the requirements.

This paper presents the developed ontology using verbal descriptions of terms, graphic representations according to the schematic language Schematic Language (SL) of the IDEF5 standard and an analytical description.

Schematic Language (SL) of the IDEF5 standard includes several types of diagrams for constructing ontology. In the framework of research, a Composition Schematics was used, which is a mechanism for graphically representing the composition of ontology classes and actually represents ontological research tools based on the principle «What consists of what». In particular, compositional schemes allow you to visually display the composition of objects belonging to a particular class [6].
The importance of developing information technology for evaluating the maturity of an IT enterprise, taking into account the principles of sustainable development, is shown in ontology in the Fig. 1. The ontology in Fig. 1 is built on the basis of concepts, the terms of which make up the dictionary of the subject area under study, and the relationships between them. The «part of» relationship is applied in the compositional part of the scheme and reflects the composition of the object; «Subkind of» - in the classification part of the scheme and indicates a type of object.

For the analytical representation, the mathematical apparatus was used, namely predicate calculus, since when increasing and refining the ontology of the subject area, it provides reliable results [17]. Each concept of domain be defined in the form of a predicate, formula, and axiom.

According to Fig. 1 sustainable development of an IT enterprise can be defined by a nonempty set $S$ :

$$
S=\left\{\begin{array}{l}
\text { directions_of_sustainable_development, } \\
\text { principles, goal No.9, tools, parts, strategies }
\end{array}\right\} .
$$

The formula for the sustainable development of an IT enterprise will be as follows:

$$
\begin{aligned}
& S=P^{S}(\text { directions_of_sustainable_development }) \wedge \\
& \wedge P^{S}(\text { principles }) \wedge P^{S}(\text { goal No. } 9) \wedge P^{S}(\text { tools }) \wedge \\
& \wedge P^{S}(\text { parts }) \wedge P^{S}(\text { strategies }),
\end{aligned}
$$

where $P^{S}-$ «part of» relation.

Axioms for $S$ are:

$\forall$ directions_of_sustainable_development $\forall$

$\forall$ principles $\forall$ goal No. $9 \forall$ tools $\forall$

$\forall$ parts $\forall$ strategies $\rightarrow S$.

According to the principles of sustainable development can be represented as:

$$
\begin{aligned}
& S=\{\text { principles }\} \rightarrow \\
& \rightarrow S_{1}=\{\text { eco-effectives, eco-equity, eco-efficiency }\},
\end{aligned}
$$

for which the formula will look like:

$$
\begin{aligned}
& S_{1}=P^{S_{1}}(\text { eco }- \text { effectives }) \wedge P^{S_{1}}(\text { eco }- \text { equity }) \wedge \\
& \wedge P^{S_{1}}(\text { eco-efficiency }),
\end{aligned}
$$

where $P^{S_{1}}-$ «subkind of» relation.

The axioms for $S_{1}$ are:

$$
\forall \text { eco - effectives } \forall \text { eco - equity } \forall \text { eco - efficiency } \rightarrow S_{1}
$$

Thus, the developed ontology can be used to create information technology for the evaluation of an IT enterprise, taking into account the principles of sustainable development. The advantages of this ontology thanks to the tools used, namely the IDEF5 standard, are accessibility, simplicity, comprehensibility and visualization for users of the ontology. According to predicate calculus as an analytical representation of ontology, the advantage is ensuring the reliability of results and ease of development for experts. It should be noted that this ontology involves the expansion, increase and refinement in connection with the boundaries of projects where it can be used. 


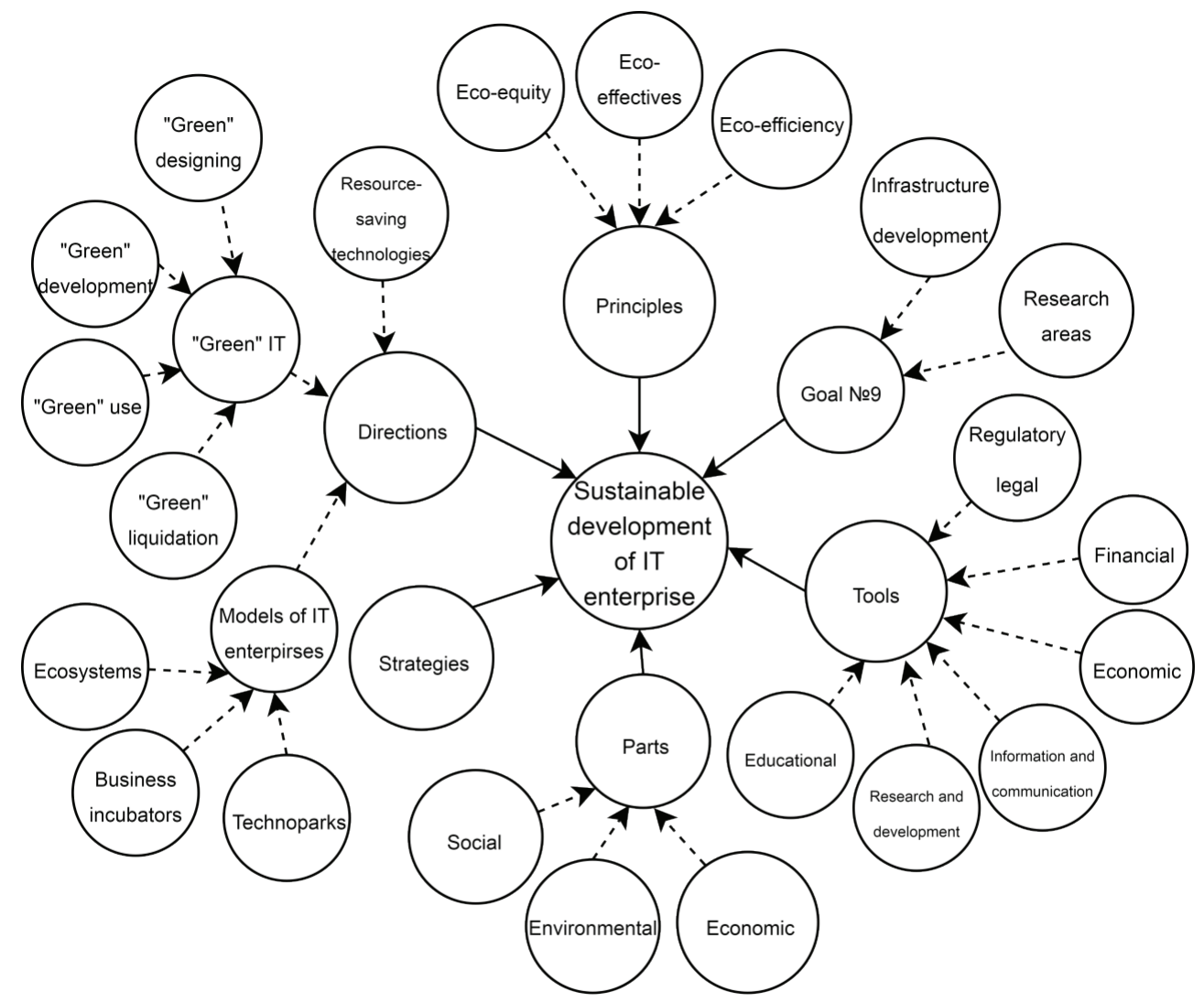

Fig. 1. Ontological model of the domain of sustainable development of IT enterprises: $\longrightarrow$ - "part of» relation; - ----- $\longrightarrow$ - «subkinds of» relation

\section{Conclusions}

This work is the result of developing ontology for the sustainable development domain of an IT enterprise, presented using verbal, graphic and analytical specifications. The developed ontological model of the domain of sustainable development of an IT enterprise is the basis for the development of information technology for assessing the maturity of an IT enterprise, taking into account the principles of sustainable development. The developed ontology facilitates the perception and understanding of domain. The developed ontology includes three types of representation: verbal, graphic (in accordance with the IDEF5 standard) and analytical using predicate calculus. In turn, the developed ontology involves the refinement and expansion in accordance with the requirements of projects where this ontology will be used, for example, to develop an expert system for solving domain problems.

\section{References}

1. Konys, A. (2018). An Ontology-Based Knowledge Modelling for a Sustainability Assessment Domain. Sustainability, 10 (2), 300. doi: http://doi.org/10.3390/su10020300

2. Khomiachenkova, N. A. (2011). Monitoring ustoichivogo razvitiia promyshlennogo predpriiatiia. Rossiiskoe predprinimatelstvo, 1 (2 (176)), 63-67.

3. Grishakov, K. R. (2013). Poniatie ustoichivogo razvitiia promyshlennogo predpriiatiia. SCIARTICLE.RU, 3, 126-134.

4. Kolocheva, V. V., Titova, V. A. (2010). Ustoichivoe razvitie predpriiatii na osnove processnogo pokhoda. Vestnik IUUrGU, 7, 20-25.

5. IDEF5 Method Report. Available at: http://or-rsv.narod.ru/ Docs/idef5.pdf

6. Standart ontologicheskogo issledovaniia IDEF5. Available at: http://citforum.ck.ua/cfin/idef/idef5.shtml
7. Poriadok dennyi v haluzi staloho rozvytku na period do 2030 roku. Rezoliutsiia, pryiniata Heneralnoiu Asambleieiu OON 25 veresnia 2015 roku.

8. Proekt «Kontseptsiia perekhodu Ukrainy do staloho rozvytku do 2030 roku». Portal Verkhoznoi Rady Ukrainy. Available at: http://w1.c1.rada.gov.ua/pls/zweb2/webproc34?id=\&pf3511= $64508 \&$ pf $35401=462260$

9. Sidorov, N. A. (2011). Zelenye informacionnye sistemy i tekhnologi. Inzheneriia programnogo obespecheniia, 3 (7), 5-12.

10. Khomenko, V. A. (2011). Ekosystemy prohramnoho zabezpechennia. Visnyk Natsionalnoho tekhnichnoho universytetu «KhPI», $23,114-118$.

11. Grinenko, S. A. (2016). Systematic Mapping Studies in Sustainable IT. Inzheneriia prohramnoho zabezpechennia, 4 (28), 5-14.

12. Kharchenko, V. S. (Ed.) (2014). Zelenaia IT-inzheneriia. Tom 1. Principy, modeli, komponenty. Kharkiv: Nacionalnii aerokosmicheskii universitet im. N. E. Zhukovskogo «KHAI», 594.

13. Kharchenko, V. S. (Ed.) (2014). Zelenaia IT-inzheneriia. Tom 2. Sistemy, industriia, socium. Kharkiv: Nacionalnii aerokosmicheskii universitet im. N. E. Zhukovskogo «KHAI», 688.

14. ISO 14001. Environmental Management Systems - Requirements with guidance for use.

15. BS 8900-1:2013. Managing sustainable development of organizations.

16. BS 8900-2:2013. Managing sustainable development of organizations. Framework for assessment against BS 8900-1. Specification.

17. Kryvyi, S. L. (2010). Kurs dyskretnoi matematyky. Kyiv: NAUdruk, 352.

Popereshnyak Svitlana, PhD, Associate Professor, Department of Software Systems and Technologies, Taras Shevchenko National University of Kyiv, Ukraine, e-mail: spopereshnyak@gmail.com, ORCID: http://orcid.org/0000-0002-0531-9809

Grinenko Sergiy, Assistant, Department of Software Engineering, National Aviation University, Kyiv, Ukraine, e-mail: serggrin@ukr.net, ORCID: http://orcid.org/0000-0001-5544-2605 